\title{
DEFINITION CONSTRUCTED PROCESS IN MATHEMATICS LEARNING
}

\author{
${ }^{1}$ Syukma Netti, ${ }^{2}$ Fahruh Juhaevah \\ ${ }^{1}$ Universitas Bung Hatta, ${ }^{2}$ IAIN Ambon \\ syukmaneti@bunghatta.ac.id
}

\begin{abstract}
Abstrak
Salah satu faktor yang dapat mendukung kemampuan profesional guru adalah penguasaan guru tentang ilmu psikologi kognitif. Salah satu kajian dari ilmu kognitif adalah tentang bagaimana siswa belajar. Tulisan ini membahas tentang bagaimana pemahaman terhadap definisi berkembang dalam pikiran siswa. Seorang guru tidak hanya memfasilitasi siswa untuk memiliki konsep definisi sebaiknya sampai memiliki konsep image.
\end{abstract}

Kata kunci: konsep image, konsep definisi, mental image

\begin{abstract}
One factor that can support the teacher's professional abilities is the mastery of the teacher about cognitive psychology. One study of cognitive science is about how students learn. This paper discusses how understanding of definitions develops in the minds of students. A teacher does not only facilitate students to have a definition concept, it is better to have an image concept.
\end{abstract}

Keywords: image concept, definition concept, image concept

Sitasi: Netti, S. Juhaevah, F. 2019. Definition Constructed Process in Mathematics Learning. Matematika dan Pembelajaran, 7(1), 81-90.

\section{INTRODUCTION}

Being a professional teacher is not easy and very complex. Many aspects and knowledge must be possessed by a teacher. At least 4 competencies must be possessed by the teacher, namely pedagogic, professional, social, and personality competencies. Pedagogic competence and professional competence (in terms of mastery of material) must be bridged with cognitive psychology. Cognitive psychology is the study of how people perceive (learn), learn, remember, and think about information (Sternberg \& Sternberg, 2012). A cognitive psychologist learns how people see various forms, why they remember some facts and forget other 
facts, or how they learn something, problem-solving, understanding/reasoning, and decision making. A teacher who understands cognitive psychology theory will better understand how students learn and better understand how to teach their students.

One theory about cognitive development is the constructivist theory (Tall, 2002). Constructivist theories discuss how mental ideas are formed in the minds of each individual. Famous figures who discuss this theory are Piaget and Vygosky. The cognitive development theory of Piaget states that cognitive development occurs through a process of adaptation. Adaptation requires one to make adjustments (equilibrium) to environmental conditions and harmonize these adjustments through accommodation and assimilation (Netti, 2017). Assimilation and accommodation produce schemes (Arbib, 1990). Skemp (1982) states that the scheme is a term in the field of psychology to express mental structure.

The scheme formed from assimilation and accommodation is not always true (Subanji \& Nusantara, 2015; Netti, 2017). Subanji (2017) found there are 5 forms of mathematical concept construction errors, namely (1) pseudoconstruction, (2) construction holes, (3) mis-analogical construction, (4) misconnection, and (5) mis-logical construction. Netti (2017) found 5 models of schema structure of students when constructing mathematical evidence, namely (1) completeness of the scheme, (2) incompleteness of the scheme, (3) scheme irrelevance, (4) scheme mismatch and (5) scheme immaturity. The question that arises is why can there be errors in the construction of student schemes in solving problems. This paper discusses one of the factors that causes the formation of a wrong scheme or not according to students.

Problems with mathematics and psychology are two things that can not be separated (Drayfus, 2002). Psychological problems that are very related in teaching students is how definitions are perceived and constructed by students. For example, when we build knowledge about graph functions, we run a mathematical process, following certain rules that can be expressed in mathematical language; At the same time, most likely we produce a separate image in our minds about the 
graph of the function. Shadow in mind is called a metal image (Drayfus, 2002). In other words, we visualize the function in a way that later can help us think about that function. It can be seen here that mental images and mathematics are very closely related.

Understanding, more than just knowing or being skilled, and always considered an important goal by mathematics teachers. Understanding is a process that occurs in the minds of students. Maybe fast, one click mind. But more often, this is based on a long sequence of learning activities, where various mental processes occur and interact (Drayfus, 2002). Therefore, what it means to understand concepts or mathematical concepts is very difficult to analyze.

It is assumed that to obtain a concept means forming an image concept for it. To understand and truly understand a concept means that you must have the concept of image, the meaning must be able to associate with words. For example, to introduce an average concept, the mode and median are not enough just to introduce definitions and formulas but must be able to assemble the concept with words so that the links between the three concepts become clear.

The brain is not a purely logical entity. Complex ways of the brain whose functions are often different from mathematical logic. It is not always pure logic that gives us insight, nor is it a coincidence that we make a mistake. Tall (2002) uses the term image concept to describe the total cognitive structure associated with the concept, which includes all mental images, property and related processes. It was built for years through experience of all kinds, as changes in individuals due to new stimuli became mature. When the concept of developing images does not need to be coherent at all times. The brain doesn't work like that. Sensory input stimulates certain neural pathways and inhibits others. In this way different stimuli can activate different parts of the image concept, developing it in a way does not have to be all coherent. (Tall \& Vinner 1981)

A mature mathematician is not free from internal conflict, but he is able to connect most of the knowledge into a sequence of deductive arguments. For people like that, it is much easier to categorize this knowledge in a logically 
structured way. Thus, a mature mathematician can take advantage of this to help present material to students. Teachers of this level can aggressively provide appropriate illustrations for students to explain a particular concept. However, a student who is inexperienced as a teacher may find difficulties when understanding material in a formal form. But it becomes different if the material presented is not formal but realistic in a broader context that fits the needs of students. There are important things from students that must be considered, namely the approach to mathematical knowledge that grows as they grow: cognitive approaches that take into account the development of their knowledge structures and thought processes. All these things to become they can be like mature mathematicians at a higher level. However, on the way, they might find rocky roads that would require a fundamental transition in their thinking processes.

When students learn new things or find new problems there are at least three elements which are interrelated in the mind of students, namely the definition of concepts, image concepts and mental images (mental image / mental picture). It is assumed that the concept of image is obtained by the process of expanding the concept of definition with the support of the teacher. Meanwhile, mental image can support the formation of image concepts or vice versa can disrupt the formation of image concepts (very interesting to study). This paper is the result of informal observations of students and teachers in learning definitions. To look at it, Vinner (2002) used a framework for the relationship between concept definition and image definition.

Providing the idea of the relationship between the concept of image and the concept of definition Vinner (1983) uses diagrams in the form of two boxes or called cells that represent our different cognitive structures (just help to avoid confusion). One cell is for concept definition and the second box is for image concept. One cell or both may not work. Cell image concept can be empty of several meanings and not associated with other concept of concept. This can occur in many situations where concept definitions are memorized in a meaningless way. There may also be some interactions between the two cells. A student may have several 
image concepts about the concept of a coordinate system because they see many graphics in various situations. According to the concept of this image, the two coordinate system axes are perpendicular to each other. Then, the math teacher might define a coordinate system with two straight intersecting lines. As a result, three scenarios might occur:

1. The concept of image has been changed to include the coordinate system whose axis does not form a right angle. (definition concept has developed)

2. the image concept may remain like that. The concept cell definition will be temporarily contained by the teacher's definition but this definition will be forgotten or distorted after a short time, and when the student is asked to determine the coordinate system, he will tell about the axis that forms a right angle. (In this case the formal definition has not been assimilated.)

3. Both cells will remain as they were. When students are asked to determine the coordinate system, he will repeat the definition of the teacher, but in other situations he will think of the coordinate system as a perpendicular two axis configuration

A similar process might occur when the concept is first introduced using definition. Here, the concept of image is an empty cell at the beginning, after some examples and explanations, then the cell definition concept is gradually filled. However, that does not always reflect all aspects of concept definition. Scenarios similar to the 3 possible conditions that might occur above are shown in Figure 1 below.

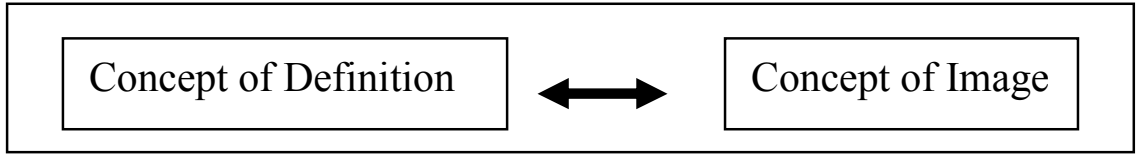

Figure 1. Interplay between the concept of image and the concept of definition The reciprocal arrow shows the interaction between the concepts of definition and the concept of image. The interaction takes place over a long time, the longer the mastery of a person is established and the more quality the illustrations are used when explaining the concept. 


\section{Concept of Definition $\longrightarrow$ Concept of Image}

Figure 2. Cognitive growth from formal concepts

The one-way arrow shows no interaction between the concept of definition and the concept of image. Most teachers at the secondary and higher level expect a one-way process for concept formation as shown in figure 2, that is, they expect that the concept of image will be formed through concept definitions and will be fully controlled by the concept of image formed

In addition to the concept formation process, Vinner (2002) also examined the condition of cell relations concept images and concept definitions in solving problems. How the interaction between the concept of image and the concept of definition is illustrated by the following 4 images. The arrows on the image represent different ways when the cognitive system functions.

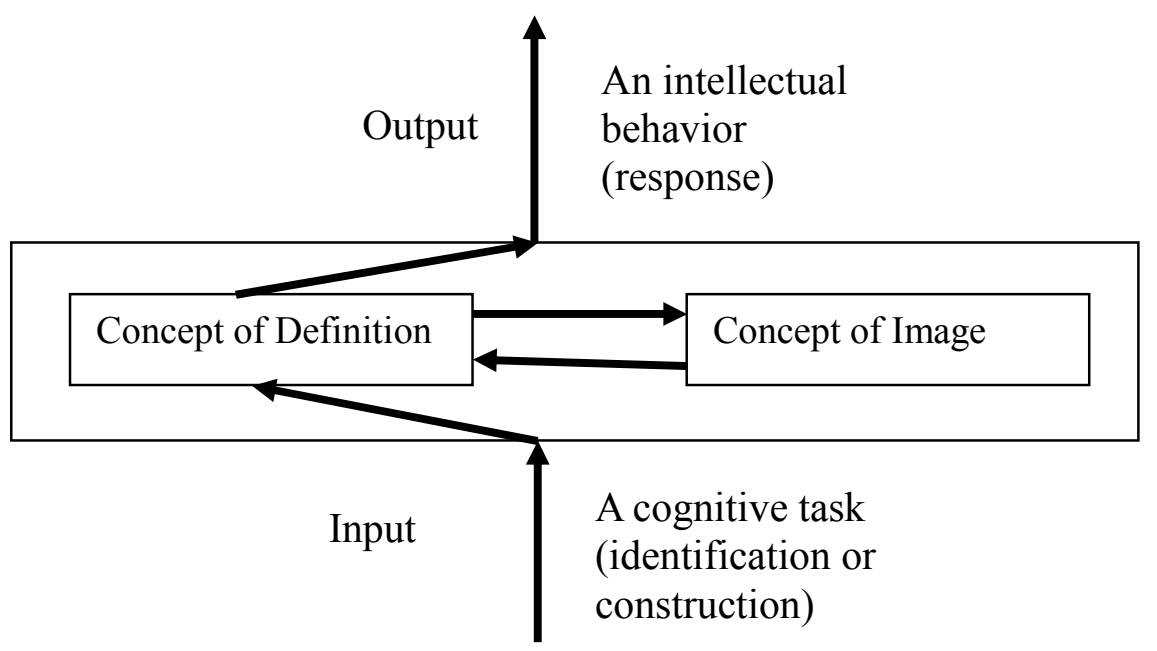

Figure 3. Interplay between the concepts of definition and concept of image 


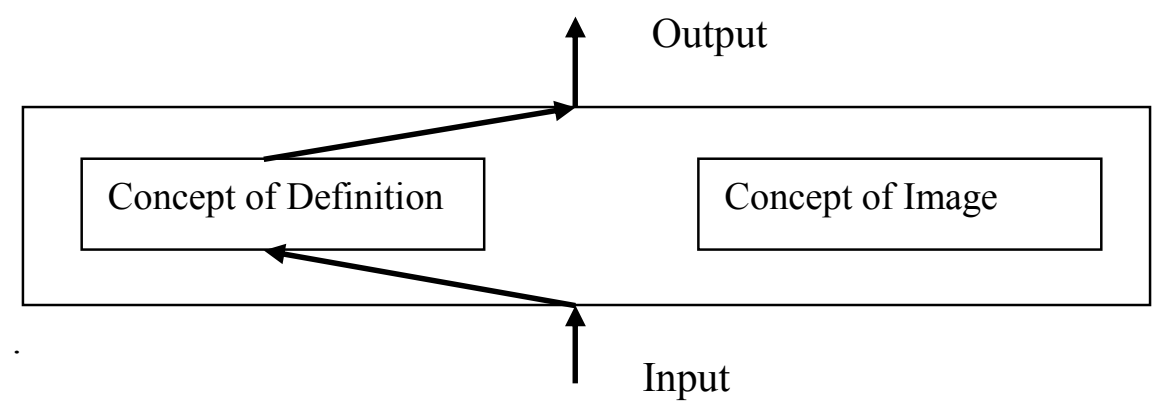

Figure 4. Pure Formal Deductive

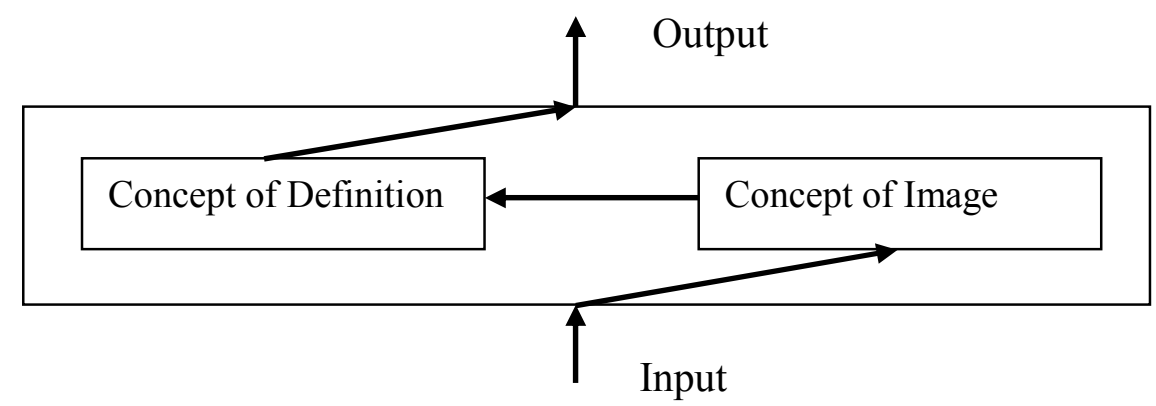

Figure 5. Deductive follows intuitive thinking

The above conditions are ideal conditions, where the intuitive mind is followed by a deductive mind. If we only think intuitively, the consequences can not be in line with the concept of definition so that the results obtained can not be guaranteed the truth. Intuitive thoughts must be controlled with a deductive mind so that there is a guarantee of truth. Vinner (2002) found that in everyday practice the patterns that are commonly found are as shown in figure 6 below

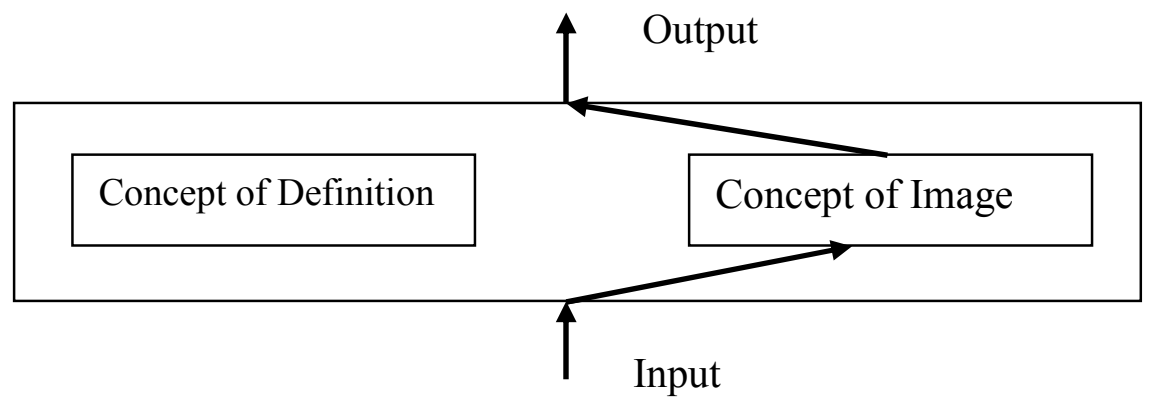

Figure 6. Intuitive response

The response to a problem that is solved or during the problem-solving process only uses intuition and does not require concept resolution. 
Habit of thinking in daily life it tends to be patterned thinking like this figure 6 .

\section{RESULT AND DISCUSSION}

The framework, about the interaction of image concepts and definition concepts when students learn new things and when students deal with a problem discussed by Vinner (2002), does not relate the discussion to how the teacher presents material when providing new material or new definitions. It is assumed that the framework is prepared in the condition that the teacher has been in a condition of having a satisfactory image concept, so that only the process discussed in the mind of the student is discussed.

Based on the findings from the results of non-formal observations and the existing phenomena it is assumed that what was concluded by Vinner (2002) was found in most teachers and prospective teachers. That is, most of the teachers formed today are intuitive type teachers. This is found when we ask prospective teacher students to mention one definition or when they present material in a practical class or when the teacher's PLPG activities.

As stated earlier that the mental image is thought to be able to disrupt or support the formation of the concept of image. The following example illustrates teacher intuition which inhibits the development of definite concepts and the concept of image.

Author : How do you explain the concept of integers?

Teacher : Use the word good/bad, big/small. Say that the right is a positive sign in mathematics and the left one is exemplified in the left hand or all the left is of less value in mathematics, the name is negative.

The teacher's way develops the students' image concept above has not been able to direct students to construct the concept of definitions of negative integers. Using the words "big" and "small" can confuse the concept of the definition of integers because large and small can disrupt children in understanding negative numbers. In fact, negative numbers in small large sizes are very different from positive integers. At integers the greater the number that is selected the greater the 
value of the number. As for negative integers, the number is large but the value is small $(-100<-2)$.

Thus, the terms "good" and "bad", using this word will build the concept of image in students that negative numbers are bad things. Negative integers are not symbols, for something bad. The concept of image that the teacher has that is used to help children understand the meaning of negative integers creates a mental image that is not appropriate for students.

As we know, negative numbers are symbols that are used to indicate something that is below a certain standard or normal condition. Suppose the size of the height uses the above ground position as a standard. The height of the kite is 10 meters, meaning that the kite is 10 meters above the ground. What about a rabbit in a hole with a depth of 1 meter. What is the number symbol to show the position of the rabbit from the ground, then the -1 meter symbol appears, which means 1 meter below the surface of the ground. Is -1 bad. The answer is not necessarily. Can mean bad if the hole is narrow and dangerous for the rabbit. Can not be bad, if the rabbit farmer deliberately makes a hole with a size that is wide enough as a rabbit place so that the rabbit does not go far.

It is very important to connect our intuition mind with the concept of definition so that the concept of the image formed does not deviate from the real theory. The teacher can not just follow what he feels is right. The teacher must update his knowledge. It is possible that the knowledge gained in the lecture is obtained by presenting intuition.

\section{CONCLUSION}

The explanation above wants to provide how the connection between the concept of definition, the concept of image and mental image. The concept of definition is something that tends to be stiff and die if it is not developed into an image concept. However, teachers must be careful in directing students to build image concepts because mental images can play a positive role can also play a negative role. 


\section{REFERENCE}

Arbib, A. M. (1990). A Piagetian Perspective on Mathematical Construction. Synthesis. Volume 84, Issue 1, pp 43-58 doi:10.1007/BF00485006

Dubinsky. (2002). Reflective Abstractionin Advanced Mathematical Thinking In David Tall Advanced Mathematical Thinking Kluwer Academic Publishers New York

Mulyono. (2011).Teori Apos dan Implementasinya dalam Pembelajaran. JMEE, I (1).

Netti, S., Sutawidjaya, A., Subanji \& Mulyati, S. (2017). Skema Berpikir Mahasiswa Ketika Mengostruksi Bukti Matematis. Prosiding SI MaNIs (Seminar Nasional Integrasi Matematika dan Nilai Islami) No.1, Hal 547555. p-ISSN:2580-4596; e-ISSN: 2580-460X

Netti, S. Nusantara, T., Subanji, Abadyo, Anwar, L. (2016). The Failure to Construct Proof Based on Assimilation and Accommodation Framework from Piaget. International Education Studies; 9(12)

Subanji \& Nusantara, T. (2016). Thinking Process of Pseudo Construction in Mathematics Concepts. International Education studies, 9(2), 17-31

Subanji. (2017). Defragmentasi Struktur Berpikir. Malang. UM Press

Skemp, R. Richard. (1982). The Psychology of Learning Mathematics. Great Britain. Harell Watson \& Vinely Ltd

Stemberg, R.J \& Stenberg, K. (2012). Cognitive Psychology. Sixth edition. Wadsworth, Cengage Learning. 